\title{
Elections and Implementation of the Law of Elections in Albania
}

\author{
Prof. As. Dr. llir Berhani \\ Universiteti i Shkodrës "Luigj Gurakuqi”, Shkodër \\ berhanijuris@libero.it
}

\section{Doi:10.5901/mjss.2015.v6n2s5p155}

\begin{abstract}
After the overthrow of the dictatorial system as in Albania in the year 1990, elections are the only legitimate way for the creation of government. In the new political system pluralist democratic governance based only on general elections, free, equal, and periodicals. It became necessarya series of constitutional and legal regulations for elections and election rights. With new laws were arranged particularly and completely realization of this right. The main legal obstacle to democratic elections was the socialist constitution of 1976. Step immediate legislative, that was taken, socialist constitution was abrogated, in force since 1976 in Albania, and adopted a new basic law, with temporary power, until the adoption of a new constitution, which will be the basis of a new political system which was decided in our country after 1990. The main legal acts arranged elections and election law in the new political system are: first, constitutional normative acts, such include law for "Major constitutional provisions" adopted in 1991, constitutional amendment " On rights and freedoms of man", adopted in 1993 and constitution, adopted in 1998. Second, laws, in the which belong the laws on elections and electoral code adopted in 2000. Thirdly are other normative legal acts that governing the conduct of elections and the exercise of the right of election in the our country. The paper treats the elections as the only way to govern, governments that do not come from elections are considered unconstitutional and not legal. The paper treats the constitutional guarantees for elections and election law. The right of election is considered political fundamental constitutional right, This right is guaranteed by the constitution, is the backup of the constitution and can not be limited or denied to any other normative act. The paper treats the the right adjustments election to election law (Election Code). The Constitution orders that the exercise of the right of election, as constitutional political right,be regulated by a special law. The paper treats the provisions of the electoral code to ensure the exercise of this right policy. The paper also deals with the regulation and protection of the right of election from other legal acts, primarily criminal legislation and administrative. In criminal law prescribes a number criminal offenses that directly protect elections and election law. Place on paper has the jurisprudence of the Constitutional Court and the ordinary courts about the elections and election law.
\end{abstract}

Keywords: electoral code, the constitution. the right of election, election freedom constitutional justice.

\section{Elections and Governance}

With the political changes in Albania the only way for government ee election. Has no other way tool and to achieve governance New democratic system determines a representative government non government of a class, just like in western democratic systems european and american. In Western Europe and in America governments are representative and realized only through elections. Citizens elect representatives who will govern by voting. In representative government electionstransformed in a necessary element of governance. Legitimation the governance provided only by elections. "Organization and development the regular elections and free is extremely important moment for the constitution and legitimization of political power. Only through this election becomes possible to broadcast directly political will of the people in the state. For these reasons, the elections are more important and sacred for democracy ". 1

For this reason it was urgent abrogation of socialist constitution, in which the government based not on elections, and represented the dictatorship of the working class. ${ }^{2}$ In the new political system, governance is representative of the citizens. It was needed a new constitution to regulate governance. For consistency with urgency was adopted in 1991Law on "Major Constitutional Provisions" which determined that governing bodies in the country derive from the elections,

1 Xh.Zaganjori "Democracy and the rule of law" Tirana, 2002 p. 28-29

2 Law 7941 dated 29.04.1991 "On the main constitutional provisions" Article 45. ". Constitution RPSSH adopted on 28.12.1976, and its subsequent amendments are repealed." 
ranging from assembly which is elected by democratic elections. ${ }^{3}$ However, a detailed arrangement of the elections and the right of the elections, became the law "On the rights and freedoms" adopted in 1993. ${ }^{4}$

Finally, the role of elections and elections to the government report, in our country, was arranged by the fundamental law of the state, the constitution of 1998. The constitution establishes the elections as the only means political who ensures and guarantees the democratic governance of the country. Legitimate constitutional government based in elections, realized only through freedom equal, general and periodic elections,. In this sense, the elections are the only means political for changed the governments in our country. Provision of the Constitution, which regulates election report is with governance, excludes all other means and any other way for the formation of the government in Albania. Government comes only from the elections and there is no other political alternative. The Constitution prohibits any alternative for formation of government and considered unconstitutional any government that does not come from elections. ${ }^{5}$ But analyzing this provision conclude that there are not enough for the government to come out of the elections, but only by elections who are freedom. Elections freedom, according to the constitution, means freedom to participate in elections and freedom to choose the most liked alternative governance. With this provision, constitution in way formal legal guaranteeing freedom, elections and prohibits the approval / extraction of legal norms that infringe freedom elections, considering them as unconstitutional. However, the relevant provision foresees that the elections should be equal and prohibits, considering unconstitutional, legal norms that violate equality of citizens in elections. Constitution, with this provision, forcing election laws to guarantee and ensure equal elections, equal value of vote and equal number of votes, for all citizens without exception. Another aspect that sets this provision, means that government comes only from the general election and not by elections partial. General election, with the participation of all citizens with voting rights, and on the entire territory of the country, are the condition that determines provision of the Constitution to form a government. This means that partial elections not constitute reason for the collapse and formation of government in our country. The relevant provision makes and another adjustment for election as a tool of governance. This provision stipulates that government elections must be periodic. And the constitution provides that government elections held in our country every four years, when representative body, the assembly. the mandate ends. So, the constitution obliges our state every four years to hold elections for representative body. ${ }^{6}$ The state has a constitutional legal obligation that derives directly from the Constitution, prepare periodically every four years, the holding of elections. With this provision the Constitution does not define a passive position of the state for the elections. Constitution goes in the same direction with the European Convention on Human Rights. The constitutional provision is in accordance with Article 3 of Protocol 1 of the Convention, that legally obliges states Parties to develop elections in reasonable period, determining the Contracting States obligations of positive character to create institutional infrastructures, purpose the realization of the right to vote and the right to be elected to the legislative body. One such obligation / liability is provided by the European Court of Human Rights in the case of Mathieu-Mohin \& Clerfayt v Belgium: ". . . First obligation in the relevant field is not simply an abstention or non-intervention, as in most of the rights with political and civil character, but the obligation to take measures with positive character for "holding" of "democratic elections". 7

In command of the constitution, election law, the election code provides that "Elections are periodic". ${ }^{8}$ Like the constitution and electoral code goes in full compliance with Article 3 of Protocol 1 that the election must be made in reasonable intervals. "The High Contracting Parties undertake to organize at reasonable intervals elections . . . ". ${ }^{9}$ It should be noted that Convention organs not defined and have not fixed this reasonable time interval. But, nevertheless, it is accepted by these bodies to the convention that reasonable time limits can be between five or six years. Another aspect that provision of the Constitution has determined is that the elections for the formation of the governing bodies of the state, should be democratic. ${ }^{10}$ With this that provides this provision of the constitution conforms to the standards that define for elections the European Convention and Article 3 of Protocol 1, wheredetermined that "Parties ... undertake to organize ... freedom elections by secret ballot, under conditions which will ensure the free expression of the opinion of

\footnotetext{
${ }^{3}$ Law 7941 dated 29.04.1991 "On the main constitutional provisions" Article 3 pg 3 "Representative bodies are elected by freedom, general, equal, direct and secret vote".

${ }^{4}$ The law "On the rights and freedoms" dated 31.03.1993.

${ }^{5}$ RA Constitution Article 1/3 Governance is based on a system of elections that are freedom, equal, general and periodic.

${ }^{6}$ RA Constitution Article 65/1

${ }^{7}$ Report on the study approach legislation with the European Convention on Human Rights "Tirana 2003 f..55

8 Electoral Code 2008 Article 3/1

${ }_{9}^{9}$ Protocol 1 ECHR Article 3. "The High Contracting Parties undertake to hold freedom elections at intervals reasonable by secret ballot, under conditions which ensure the free expression of the opinion of the people in the choice the legislature ".

10 Constitution Article 1/3
} 
the people ..." "11

\section{Right of Election is a Constitutional Right}

Based on the provisions of the constitution electoral rights, includes in its content both right; the right to vote and the right to be elected to representative bodies and government. ${ }^{12}$ In the specific provisions in the constitution are directly regulating the right to vote and be elected. Moreover, the constitution defines the right of election as a fundamental political right of every citizen, which provided and protected by the constitution. The Constitution contains provisions that oblige the state and state bodies to respect the constitutional right of election. These provisions oblige the state and state bodiesapprove acts and oblige them to act to ensure the realization of this right by the citizens. In this sense, the state has a positive legal obligation not only to respect the right of citizens, but also the obligation to adopt laws that regulate and protect the realization of this right. ${ }^{13}$ The right to vote is a right ". . . to which public power authorities in fulfilling their duties, must respect ... and to contribute to its realization"14 Protocol 1 , Article 3 not only considers the right of voters a fundamental political right, but is among the few provisions which establish a positive obligation for the state. However Protocol gives freedom to each state to choose the electoral system and to determine the representative body. Even the European Convention on Human Rights only in this provision clearly involves only basic political right. . In this direction in our constitution the right to elect is defined as a general right, as the right of all citizens, that fulfilled two conditions are citizens and have reached eighteen years, including on election day. ${ }^{15}$

The right to elect and be elected has every citizen. But defining the right election as a general political right of citizens our Constitution places a restriction on the electoral rightsage limit, eighteen years. Constitution considers reserve of the constitution determining the terms of the possession of the right to vote, citizenship and adulthood. However, the constitution considers constitutional reserve the prediction of cases that restrict or prohibit the development and implementation of the right of election. The Constitution has provided only two cases of prohibition or restriction on the right to vote (mental incapacity declared by a court decision final) pg 2; and removal of personal freedom, imprisonment (persons deprived of their liberty and are suffering sentence of imprisonment who, according to the constitution, in this provision, owning only the right to vote, pg 3). ${ }^{16}$ Even in this aspect the constitution is approximated with the European Convention on Human Rights. Restrictions of this type are provided and permitted and under this Convention. The European Convention provides that states have the space to set conditions for the exercise of this fundamental political right of citizens. In this direction, the European Court of Human Rights, in its decisions, has accepted limitations of the election right. The Court has recognized that states parties have wide margin of appreciation in this field. However, it should be noted, however, that the European Court has not adopted a closed list, to limit or derogate from this right subjective. ${ }^{17}$ In the spirit of the Convention and the decisions of the European Court and of the constitution, the Electoral Code provides that, "All albanian citizen who has turned 18 years old on election day and that meets the necessary requirements in this code has the right to vote in elections for parliament and local government bodies "18 The right, the citizens to elect and to be elected, is a fundamental political right of citizens double. It includes the right to vote for the election of representatives and also includes the right to elected in functions public and state functions. ${ }^{19}$ Based on what is provided for in the constitution, it follows that restrictions of right of election that overcome the limitations provided for in the constitution considered unconstitutional. Restrictions, over constitutional reserve, become the subject of constitutional adjudication by the Constitutional Court and abolished. Election laws and all other normative acts for elections must guarantee the right of election in two aspects: in terms of the right to vote and in terms of the right to elected. Because restriction of the right of election are the reserve of the constitution, and the constitution is the highest normative act in the legal hierarchy, the constitution has provided cases of violation of this or restricting the right of election. So, the right to elect is a fundamental right political constitutional of individual. This right can not be violated by law and for consistency no individual is excluded from the possession of right to vote. However, the Constitutional Court of Albania and the European judicial practice acknowledged and considered justified the imposition

11 Protocol 1 ' of ECHR. Article 3

12 Kushtetuta neni $45 / 1$

${ }^{13}$ Assembly on the implementation of the constitutional obligation approved KodinZgjedhor, in 2000, amended in 2003,2008,2012

${ }^{14}$ Report on the study approach legislation with the ECHR "Tirana $2003 f . .56$

${ }^{15}$ RA Constitution Article 45/1

${ }^{16}$ Report on the study approach legislation with the ECHR "Tirana $2003 f . .57$

17 Report on the study approach legislation with the ECHR "Tirana 2003 f..56.

${ }^{18}$ Electoral Code 2008 Article 3.1

${ }^{19}$ RA Constitution Article 45/1 "Every citizen ... has the right to elect and be elected. " 
of restrictions on the realization of the right of election, such as age, place of residence and registration on election lists. This means that citizens to realize the right to vote, to vote in elections is not enough to be eighteen years old, but must be registered in voter lists and to vote in person at their residence stable.

\section{The Implementation of the Right of Election}

Albania has adopted legislation comprehensive and democratic, in level standards prescribed and delivered in Europe and in other democratic countries, which constitutes the legal basis necessary for recognition of the right to vote to all citizens and regulating the legal side, so a detailed and the realization of the right of election as the main political rights. Normative legal base to ensure legally vote, election rights, are kuahtetuta, electoral code and laws and other acts. Moreover, in international reports on the elections held in our country during the period 1991 -2015 election normative basis is identified from internationals as an aspect of the achievements made by Albania towards approximation its legislation in the field of elections with international law in general and in particular with the European legislation. By underlined this aspect reporters OSCE / ODIHR have affirmed that the elections are regulated by a comprehensive legal framework, including mainly the Constitution, amended for the last time in 2008, and the Electoral Code of 2008, amended for the last time in July 2012. This legislation, of european standards, constitutes, in this way, the necessary normative, formal legal for democratic elections. Other laws applicable to elections include the Law on Political Parties, Meetings Law and the Penal Code, the Code of Administrative Procedure and the Code of Civil Procedure, which apply, respectively, in the proceedings of election commissions and courts, and the Law on Gender Equality containing provisions which ensure equal gender representation in election administration bodies and in parliament. ${ }^{20}$

But, however, the implementation of the right to vote in our country has experienced a series of deviations, which has brought as a consequence negation infringement and violation of the right to elect, in both aspects, as the right to be elected to representative bodies and right to vote. The main consequence that is derived from these deviations has been distorting the results of the elections or manipulation of the results of the elections. For these reasons, in many cases, the representative body elected at the conclusion of the election process, not reflected correctly and adequately map, or political geography of the country. ${ }^{21}$ Because elections are the way, are the only means constitutional and legal for the coming to power of political forces, The main political issuefor parties,since installing the new political order, became and remained elections. For these reasons, the parties have used all legal and political means to acquire them. However, this brought to consequence thatelections to be and issue more fragile in new political system. Consequently, political parties, given that they are the main subjects the election, used from the beginning and even today use highly legal and illegal machinations to win the elections. Election Wins is also win of power,government victory. Legal and illegal machinations used by the parties in elections often have been violating election, and, violating the electoral outcome, bringing in governance not real election winners. ${ }^{22}$

\section{Violations of Right of Election}

Elections was made one coveted issue for all political parties were created in our country after allowing political pluralism. ${ }^{23}$ Parties to come to governance should win the elections. Consequently, the political struggle to win elections presented harsh. Furthermore, parties seeking at any cost come to power using any form and means to win elections. Tools and forms, which are used by political parties to manipulate and violated elections in our country are different. But, in the paper treated just some ways, forms the tools more frequent and more identified, violations that have affected more in deviation and violation of this right. One form applied in almost all elections held in our country is not giving citizens in time of identification documents. Without documents of identification citizens, even though they are eighteen years of age and have the right of election, can not exercise their right to vote, so can not vote in elections. Citizens, which for lack of identification documents, can not vote, were not negligible, but have been a significant number that has always influenced the outcome of elections. By highlighting this form of violation of the election, as one of the most visible forms that marred the elections. report of OSCE ODIHR, for 2009 elections in our country, outlined in its content that . . most significant

${ }^{20}$ Raporti i OSBE / ODIHR 2013 "Për zgjedhjet në Shqipëri".

${ }^{21}$ Megadushku in 2001 elections and manipulation of elections in 2009

${ }^{22}$ Raport pë zgjedhjet e 1996

${ }^{23}$ On December 12, 1990 was created the first opposition party in Albania after the full 45 years, the Democratic Party (DP). Creating PD was followed by other parties that were created after the announcement on 15 December 1990 by the decree of the President of the Law "On political pluralism". was established Republican Party (RP), Ecological Party and Omonoia a political organization of minorities in Albania. 
debate in the general election of 2009, politically, was connected with delivery of ID cards. Were declared datawith numbers, but the inaccuracies in these data prompted the opposition to accuse the government for intentional manipulation. This issue was further complicated because the discretion of the Ministry of Interior, from 729. 020 citizens without a passport, about 160,000 to 260,000 were abroad without valid documents. On election day, were not processed only 3. 321 applications submitted by 1,402,361; 77. 751 new identity cards were not withdrawn. 256. 792 citizens, who were registered in the database of persons without a valid passport, did not apply for a new identity card. There is a significant discrepancy between male and female citizens, especially among those aged from 21 to 50 years. It is likely that many women who are married and have changed their surname, to remain registered in local registerswith Their surname of maiden, therefore listed twice . . . . Over 2,000 voters with disabilities who do not have valid passport, could not apply for a new ID card, due to access difficult or impossible in application centers. ${ }^{24}$ The conclusion was evident that, in the elections of 2009, a significant percentage of citizens can not vote, because it did not possess a passport or an identity card.

The electoral code provides that the right to vote is personal. Code obliges citizens with voting rights vote personally. Provisions of the electoral code. that regulates the exercise of the right to vote, obliges a citizen to vote himself. According code citizen votes by being personally present at the polling station. But the electoral code provides that voter comes only once in the voting center, and that the elector enters only in the secret booth where he votes. Zgjesësi is obliged to vote in secret, votes liberated from any influence. Based on the election code it's violation open ballot and vote for other people. Election Code provides only one way to exercise the right to vote, the elector must be present to vote at the polling station and voter votes only. ". . . the voter enters only in the secret booth . . ." $25 "$. . . the voter votes only for himself . . . "26 To ensure personal vote, Code provides criminal responsibility for members of the Voting Center Commission, if they allow a voter to vote more than once ..." "27 In international relations for elections are identified many forms that are used and violated directly personal character of the vote, as family voting and voting on behalf of others. ... International reports, highlighting this aspect, underlined that serious problems are, wide spread of family voting, voting on behalf of others, all cases where the voter lists had seemingly similar firms, the same person who "helps" more than one voter, attempts to influence voters, and pressure on voters or on election officials. . . " 28

Ways more evident with influence direct in election result has been the manipulation of election results during the counting process. In many cases are excluded from the count voting centers, and are not included in the final result with various pretexts. One such case was identified in the 2001 elections. Central Election Commission ordered not included in the final result four polling stations in a electoral zone. This was in violation of the constitution and the electoral code, guaranteeing the right to vote and ensure its exercise and consideration and count each vote. Order of the Body Central Election was appealed to the constitutional court. The Constitutional Court decided the repeal of the order by ordering the counting of votes in these electoral centers. Arguing the decision Constitutional Court notes that the electoral code guarantees count each vote and obliges electoral bodies to counted in determining the election outcome of all votes in each constituency and in every polling station, not allowing these bodies on this aspect to exclude the counting of votes in any polling station. ${ }^{29}$ From reporters OSCE / ODIHRIT, for 2003 local elections, reported a negative evaluation of the counting process in 38 percent of polling stations where the count was observed. While 43 percent of polling stations, where observers were present, were reported significant procedural errors and enough deficiency. ${ }^{30}$ Deficiencies in counting and manipulation of results in the counting process was repeated in the general election of 2009. According to the final election report, presented by the OSCE / ODIHR, According to the final election report presented by the OSCE I ODIHR, the ballot counting was rated bad or very bad in 22 places Counting of votes from 66 such that were total of. ${ }^{31}$ This was the distortion of election results in the $1 / 3$. According to this data the vote is violated, and the result is 33 percent of manipulate. In this case, the right to vote has been violated clearly. However, although it seems quite strange,

\footnotetext{
${ }^{24}$ Report OSCE - ODIHR 2009

25 Electoral Code 2008 Article 101/1

${ }^{26}$ Electoral Code 2008 Article 101/3

${ }^{27}$ Electoral Code 2008 Article 101/4

28 Final report of OSCE / ODIHR in 2013 elections.

${ }^{29}$ Decisions of the Constitutional Court "Electoral Process 2001" f.161. Decision No. 111/01. With this decision, this court considers unconstitutional decision dated 08.08.01 nr.219 CEC with which he was ordered not to be included. With this decision, this court considers unconstitutional decision dated 08.08.01 nr.219 CEC with which he was ordered not included in the final result table of the area 82, four polling stations. The Constitutional Court found that the CEC is out of power and ... has violated the constitutional right to vote ... of voters of these polling stations ... which speaks to Article 45 of the Constitution,.

30 The OSCE / ODIHR in the 2003 election

31 The OSCE / ODIHR in 2009 elections
} 
elections were considered regular and the result was certified, but only from one side of. The opposition did not accept the results of the general elections of 2009. The election result was rejected as the manipulated throughout legislature. For this reason, the opposition boycotted the proceedings of the representative body to the time limit, set by the constitution, in loss of representation mandates.

Another way of repeatedly of the violation of the right to vote in elections is a violation of the secrecy in voting, although the Constitution establishes that the vote is secret and citizens enjoy the freedom to vote. Election observers in our countryidentified several cases of violation of secrecy in voting. Report OSCE / ODIHR in the 2009 elections, found that 9 percent of the centers surveyed, not guaranteed secrecy of the vote provided in Copenhagen Document of the OSCE, mainly because not good space planning, limitations of this space, or the large number of people. At 2 percent of polling stations that were observed, not all voters marked a ballot inside the cabin and in 4 percent of the centers visited, not all voters folded their mark sheet, in order to ensure the secrecy of the vote. Another way of the violating the secrecy of the vote, which was highlighted was the family voting. Report OSCE - ODIHR underlines that family voting was reported by 19 percent of polling stations observed. Other ways that violated the secrecy in voting that were found were: voting on behalf of others ( 3 percent), attempt to influence voters (4 percent), cases where the same person "helping" more than one voter (4 per cent), pressure on election officials or voters (1 percent), asalso similar firms in the list of voters (4 percent). ${ }^{32}$ However, the report notes thatelection administration bodies made no legal proceedings to remedy these violations. Even political parties did not appeal to the court for the violations occurred. This is explained by the fact that all political parties participating in elections, violate the secrecy of the ballot itself, but also because subjects did not believe that the judicial process can be transparent and non-suggestible by the parties. In connection with this fact, international election reporter revealed that . . . althoughwere identified ways and diverse forms that violated secrecy of the vote, not observed frequent processes and numerous judicial processes to restore this right by all these forms of violating the election law. Not developed with trials necessary adjustments which to respect the secrecy of voting in elections. ${ }^{33}$ Repeat form of the violation of the right to vote that is recorded is falsifying the election results.

Form of repeated of violation of the right to vote that is recorded is falsifying the election results. The reports of the OSCE / ODIHR election, is evidenced by the observers, the falsification of the results of voting in some polling centers or some counting sites. According to the report, in 2009 elections reported level of different of falsification of results in 10 percent of polling stations. ${ }^{34}$ So, the outcome of the election was distorted and unrealistic. But, although is falsified, result remained such, because result, was not subject to judicial control. judicial Review of election results in this case, remains the only legal instrument that finds deformations and has the legal right to correct them. This is in line with European court decisions. The European Court has determined that, far country court to investigate and determine, in each case, infringement and violation of this right. Moreover, the court is the body that decides case by case alsothe legality of the deprivation and restriction of the right of election.

Other forms of violation of the right of election, even, and most frequently are manipulating national registry of voters and failure to register of citizens in lists of voters. These violations are repeated in all the elections held in our country. Forms used to manipulate voter register are: a- failure to register in the register of persons who have reached voting age ${ }^{35} \mathrm{~b}$ - duplicate registration of some citizens; $c$ - in the voter exclusion of citizens who enjoy this right; $d$ - not equippingof citizens with identification documents: passport or ID card; e- the relocation of voters from the voter list unit the residence in a list that belongs to another electoral area; f-not announcement the voters for their place in the list of voters and their voting center; $\mathrm{g}$ - inclusion in the voter list of individuals that have not identified residence; $\mathrm{h}$ - included in the voting list of persons who are not residents of the polling area.

Failure to register the voters in the voter lists, the voter owns this right and the removal of voters from the voter list, when the voter should be in these lists are arbitrary actions not based on law. This violation of election officials, it is

${ }^{32}$ Final Report the OSCE / ODIHR in 2009 elections

${ }^{33}$ Final Report the OSCE / ODIHR in 2009 elections

34 Final Report the OSCE / ODIHR in 2009 elections

${ }^{35}$ In the doctrine of law has two views: 1. The voter lists are a basic act, 2.shkrimi on these lists it's with declarative character and not the founder. Today, the doctrine of law, presented as the dominant viewpoint that the right of election arises from the qualities and conditions set directly by the constitution and the electoral law and the holding this right is not related at all with the inclusion of voters in the election lists. The holder of the election right guarantees this right without even being written in voter lists with a declarative decision rendered by the court. Inclusion on the electoral lists is only necessary and sufficient to exercise the right of choice, Excluded are special cases of voters who exercise this right without being registered in these lists. This refers to the exercise of the right of election by people who have not yet completed the age set by law It is the case of persons who acquire the legal capacity to act before the age prescribed by law. (Married women). Or in the case of persons who are permitted to exercise the election right of a judicial decision or a decision of the local authority. 
difficult and very complicated to prove and interpret, but brings a serious legal consequences, removes voters right of the election, which gave voters the constitution and electoral law guarantees. To take this decision the administration of the election officer does not own any discretionary powers. Legal cases for non-registration of voters on election lists and removing voters from voter lists are defined in the law. Electoral officer has no discretion but to make decisions based on determinations made in the law and in the documents, sent by other entities with which he proceeds to prove the loss of the right of election, or not to register on the list. Opportunity to remove voters from the voter lists is when the voter loses citizenship. The other case is when elktorale office takes into consideration documents proving the non-existence of the citizens in civil status register resident citizens, In this case the electoral office did not record the name of the citizens in the lists of voters who are resident in the electoral district. Reason is that election law provides that voters register only on election lists of residence, or the country where they are resident enrolled in the civil registers. In both cases reviewed above is presumed that other offices documentation submitted is correct and true. To protect the exercise of the right of election the violations that affect law of the election, as irregularities in the voting process, voting more than once, pressures during voting, vote buying by candidates or political parties and the sale of the vote by the voters, the election code provides specific provisions that define criminal and administrative punishments.

The right to vote is determined in special constitutional provisions and protected directly from it. It is part of the basic human rights guaranteed by the constitution. This right finds protection in election code, which has provided some offensespunishable, which can be performed by state bodies governing administer elections, election administration and individuals. In a chapter electoral code defines responsibilities and sanctions for persons charged with the administration of elections. ${ }^{36}$ Such acts are are: abandoning of duty by members of the election commissions. ${ }^{37}$ In the code are also provided administrative sanctions for actions that do not constitute a criminal offense orabuse of power under Article 248 of the penal code, ${ }^{38}$ which are defined as administrative violation, where not affect the outcome of elections, and are considered a criminal offense, when these actions affect the outcome of elections. In this case provided imprisonment from 6 months to two years. ${ }^{39}$

But the violation of the right to vote is protected not onlywith the provisions of special of the Electoral Code, but also by providing penal code provisions that provide for offenses against elections. The penal code provides criminal acts that violate the election: prohibition to vote; voting more than once; manipulation of election results, ${ }^{40}$ obstruction of subjects for elections to representative bodies; falsification of documents and election results; violating the secrecy of voting; giving of rewards and promises; intimidation of the voters and candidates; violation of the right of election. ${ }^{41}$ Problem controversial it's case the punishment of individuals with prohibition of the right to exercise the duties as a civil servant or public service. ${ }^{42}$ and the removal of the right to practiceprofession or activity. ${ }^{43} \mathrm{t}$ seems clear that the removal of the right to exercise a profession or activity in the sense of the Article 30 paragraph 5, differentiate from the prohibition constitutes an obstacle to public functions as defined in Article 30 paragraph 1 of the the Criminal Code. Prohibition the possibility to exercise public functions may lead to the removal of the active electoral right. . In this case the law may be provided obstruction of citizens to run for election and to exercise the function of legislators or other public functions acquired through elections.

But the election law has not defined anyprohibition for citizens who have besides the main sentence as accessory punishment prohibition of the exercise of public functions that accessed through elections. Just constitution restricts active right election, citizens sentenced to imprisonment by a final decision, who are serving a sentence. In this case, the constitution provides that the implementation of the main sentence prevents directly election of citizens in representative bodies. For this reason it is not envisaged in the Election Code, such a restriction. But in this case, by sending the decision by the court, election administration does not accept the registration of citizens in the lists of candidates. There are states where citizens lose the right election because even moral unworthiness determined by law. These persons are

\footnotetext{
${ }^{36}$ RA Electoral Code Electoral Code Article 168 ". Members of election commissions and employees of the public administration at the service of these commissions hold criminal and administrative liability under the legislation in force for violations of the provisions of this code".

${ }^{37}$ Neni170 Electoral Code "... criminal offense punishable by a fine / imprisonment 6 months to 2 years".

38 Electoral Code Article 171.

${ }^{39}$ Electoral Code Article 172.

${ }^{40}$ RA Criminal Code Chapter $X$

${ }^{41}$ RA Criminal Code Article 331.

${ }^{42}$ RA Criminal Code Article 30, 1.

${ }^{43}$ RA Criminal Code Article 30, 5.
} 
excluded from the right to elect. ${ }^{44}$

\section{Conclusions}

By addressing the issue can be concluded that in our country there is proper legislation regarding elections and guaranteeing the right of election, constitution, electoral code, and laws and other legal acts, which constitute the legal basis governing elections. From paper comes out that legislation is in full compliance with international norms for the elections, the European Koneventën Individual Rights and its additional protocols. Another finding indicates that elections in our country have presented many problems. In elections are observed violations of election law and a violation of this right in the way of diferente forms. For this reason during this period are made constantly attempt to adjustments in the legislation on elections. The most important adjustment for elections was the adoption of the constitution in 1998 and adoption of the Electoral Code in 2000. in elections held in our country are observed significant cases of violation of the right of election, which quite times have brought about the worthlessness of the elections, the case of general elections of 1996 and the distortion of election results. Constantly it's improved election legislation based on the recommendations of international organizations monitoring the elections in Albania, OSCE and ODIHR. But the last election proved the need for other changes to the electoral code, which would guarantee election truly democratic and free elections.

\section{References}

Raporti OSCE ODIHR for the 2003 local elections.

OSCE ODIHR report on the general elections of 2009

OSCE ODIHR report on the general elections of 2013

The Code of Good Practice in Electoral Matters. Strasburg. Tetor 2002

L. Omari, A. Anastasi "Constitutional Right" Tirana 2010

Luan Omari "Rule of law" Tirana, 2002

Aurela Anastasi "The constitutional right of comparing" Tirana 2009

Xhezair Zaganjori "Democracy and the rule of law" Tirana, 2002

Xh. Zaganjori, A. Vorpsi, D. Biba "Constitutional principles and fundamental rights in the jurisprudence of the Constitutional Court" Tirana 2012

Ilir Berhani "Fundamentals of election law" Tirana 2009

The Constitution of RA 1998

Election Code 2008,2012

Election Code 2008

Legal Studies Nr. 2 Tirana 2004

European Convention on Human Rights.

Additional Protocol 1 ECHR

The Constitution of the Italian Republic

Report on the study of approximation of legislation with the ECHR "Tirana 2003

"International Protection of Human Rights" OSCE-ODIHR Tirana 2000

The judicial decisions of the European Court of Human Rights, Tirana 1998

${ }^{44}$ The Constitution of the Italian Republic Article 48. "The right to vote can not be restricted except for civil incapacity or as a consequence of the a criminal decision final and in cases of moral unworthiness established by law". 